\title{
TRACKING POSITIVE AND NEGATIVE EFFECTS OF INEQUALITY ON LONG-RUN GROWTH
}

\author{
DAVID CASTELLS-QUINTANA† and VICENTE ROYUELA
}

\section{SUMMARY}

Despite extensive research, there is still controversy on the effects of income inequality on economic growth. The literature proposes several transmission channels through which these effects may take place, and even the existence of two different forms of inequality. However, empirical studies have generally not distinguished between these channels, nor have their analyses included a consideration of the two forms of inequality and their separate effects on growth. In this paper we review the theory and the evidence on the different transmission channels through which inequality influences growth. We contribute to the literature by using a system of recursive equations, following a control function approach, to empirically assess the relevance of these channels and to differentiate between two forms of inequality. In this way we have captured in a single model not only a negative effect, but also a positive effect of inequality on long-run economic growth.

Keywords: inequality, economic growth, development, control function approach

JEL classification: $\mathrm{O} 1, \mathrm{O} 4$

† David Castells-Quintana. AQR-IREA. Universidad de Barcelona. Av. Diagonal 690. Barcelona 08034, Spain. E-mail: dcastells@ub.edu

‡ Vicente Royuela. AQR-IREA. Universidad de Barcelona. Av. Diagonal 690. Barcelona 08034, Spain. E-mail: vroyuela@ub.edu 


\section{INTRODUCTION}

Much has been said about the effects of income inequality on economic growth. The on-going debate rotates around possible negative as well as positive effects of inequality on growth, characterized to work through different transmission channels, and considering the complex nature of both phenomena. One factor seems to be of major relevance; whether inequality is due to available opportunities and particular socio-economic and institutional contexts, or due to market dynamics and unequal outcomes - and uneven success. The World Development Report 2006 (World Bank 2006) differentiates between equality of opportunities and equality of outcomes. While unequal opportunities are detrimental for development, unequal outcomes generate necessary incentives for capital accumulation, innovation and economic growth; "inequality of opportunity is wasteful and inimical to sustainable development and poverty reduction" but there is an "important role of income differences in providing incentives to invest in education and physical capital, to work hard, and to take risks (WDR 2006)." Similarly to the WDR 2006, Easterly (2007) refers to structural inequality - due to socio-institutional factors - and to market inequality - due to market forces. While the former relates to inefficient institutions, low human capital investment and underdevelopment, the latter relates to uneven success in free markets. More recently, Marrero and Rodriguez (2013) follow the same argument: they refer to income inequality as a composite measure of inequality of opportunity and inequality of effort, which may affect growth through opposite channels. In any case, structural inequality (or inequality of opportunity) is expected to have a negative effect on subsequent economic growth, while market inequality (or inequality of effort) is expected to have a positive effect.

The complex influence of inequality on the dynamics of economic growth has again attracted attention of the scientific community after the world financial and economic crisis of 2008. Several authors have placed a strengthened emphasis on the role of inequalities in the growth process of the last decades, but also on the role of the dramatic rise of these inequalities in many countries as a cause of the crisis itself (Krugman 2008; Stiglitz 2009; Brescia 2010; Rajan 2010). According to these authors, currently high levels of inequality help to explain evident deficiencies in terms of economic performance, which have accumulated over the long run.

In this paper we conflate the literature on the different transmission channels for inequality to have an effect on growth, and the idea of two different components of inequality. By using several variables - 
that we relate to the different transmission channels - we decompose the variance of inequality using a system of recursive equations by means of the Control Function Approach (CFA). Our aim and contribution is to provide empirical evidence on the two opposing relationships between inequality and long-run economic growth whilst highlighting the relevance of the different transmission channels through which inequality operates. Our first main finding is that inequality indeed influences long-run economic growth both positively and negatively. Secondly, we argue that the negative influence accounts for roughly 80 per cent of the total effect in the sample of 51 countries analysed. Interestingly enough, we have identified the proportion of mountainous land as a powerful geographical determinant of inequality levels across countries, which, to the best of our knowledge, had not been considered before in the literature on inequality. Finally, we found that the role that each channel plays may depend critically on the circumstances of each country, with the negative influence of inequality being significant in developing countries. These results are crucially important for policy makers, as their challenge is to find out how, and not just if, inequality is affecting the process of economic growth.

The remainder of the paper is organized as follows. Section II briefly reviews the empirical evidence on the effects of income inequality on economic growth, and also the theory and evidence on the different transmission channels through which these effects occur. Section III sets out our model and empirical strategy. Section IV presents the database. Section V displays the main results. Section VI performs several robustness checks. Finally, section VII concludes.

\section{THE DIFFERENT EFFECTS OF INEQUALITY ON ECONOMIC GROWTH: LITERATURE REVIEW}

The traditional econometric approach to assessing the overall impact of inequality on growth has introduced a single measure of income distribution in an economic growth model. ${ }^{1}$ Along these lines, there is seemingly conflicting evidence in the literature. On the one hand, several authors support the idea of a negative effect of inequality on long-run growth (Alesina and Rodrik 1994; Persson and Tabellini 1994; Clarke 1995; Perotti

\footnotetext{
1 The most used measures are the Gini coefficients and the Theil indices. Some authors have also worked with different shares and ratios of the percentiles along the whole distribution of income. On one side, the percentage of the third quartile has been of particular interest to capture the weight of the middle class, on the basis that having a strong middle class boosts economic development (Easterly 2001; Partridge 2005). On the other side, the use of different percentile ratios allows for a focus on differentiated effects depending on the specific distributional forms of income (Voitchovsky 2005).
} 
1994, 1996; and Easterly 2007, among others). These results are based on cross-section analyses, an approach that, to the best of our knowledge, has never provided evidence of a positive effect. On the other hand, other authors have found a positive impact of inequality (Forbes 2000; Barro 2000; Chen 2003 and Voitchovsky 2005, among others). However, this positive impact relies on panel data analysis and is either associated with short-term economic growth (Forbes 2000) or is dependent on countries' income (Barro 2000), on the initial income distribution itself (Chen 2003), on the profile of inequality (Voitchovsky 2005), or on the process of urbanization (Castells-Quintana and Royuela 2014). The main argument for using panel techniques is that they allow controlling for omitted time-invariant factors and addressing how a change in a country's level of inequality will affect growth within that country (Forbes 2000). When using fixed effects, however, if the underlying causal factors in the growth process are persistent, the long-run cross-sectional effects will be subsumed into the fixed effects (Fallah and Partridge 2007). Indeed, as Forbes (2000) highlights, it is interesting to identify the time-invariant variables, omitted in panel analysis and that could generate the negative bias in the inequality coefficient in cross-country growth regressions, as well as to evaluate the different channels through which inequality, growth, and any other variables are related. Removing time-invariant factors, which, as we will see, are precisely those to which the negative effect of inequality is related, limits the possibility of empirically assessing the role of the different mechanisms behind the impact of inequality on growth. ${ }^{2}$

The literature provides theoretical justifications for both a potential beneficial and a potential adverse effect of inequality on the process of economic growth. ${ }^{3}$ In particular, while classical and neoclassical approaches have underlined a beneficial effect of inequality on growth, modern perspectives highlight potential adverse effects of inequality (Galor 2009). However, some approaches predict both a potential positive or negative effect. ${ }^{4}$

\footnotetext{
2 On a similar line, Davis and Hopkins (2011) have recently argued that panel techniques are not very informative about the relationship between inequality and long-run economic growth.

${ }^{3}$ Ferreira (1999) presents "a brief overview to theories of growth and distribution", including a review of three mechanisms that give rise to an effect of distribution on growth; political economy channels, capital market imperfections and social conflict channels. More recently, Ehrhart (2009) and Galor (2009) also present a short, though exhaustive and comprehensive overview of the theories and empirical evidence on the relationship between inequality and economic development. Neves and Silva (2013) provide a critical survey of the empirical literature trying to explain the sources of conflicting results.

${ }^{4}$ Barro (2000) provides a good understanding of how some approaches predict at the same time a negative and a positive effect on growth. As Barro notes, even under the socio-political instability approach, lower inequality may not lead to higher growth. If economic resources are required for the poor to effectively threaten the socio-political stability, then income-equalizing transfers promote stability only to the extent that that they do not encourage the poor to involve in disruptive actions rather than work.
} 
On main mechanism for inequality to influence long-run economic growth is through institutions; (structural) inequality reinforces bad institutions, low human capital investment and therefore underdevelopment (Engermann and Sokoloff 1997; Sokoloff and Engermann 2000; Bourguignon and Verdier 2000; Acemoglu 2005; Easterly 2007). Factor endowments, according to this mechanism, are a central determinant of (structural) inequality and can be used to assess the causal inequality and development relationship (Easterly 2007).

It has also been argued that inequality affects growth due to increased socio-political instability and the risk of (violent) conflict, which translates into uncertainty of property rights and reduces investment (Alesina and Perotti 1996). Additionally, stability-threatening activities represent an unproductive waste of resources and reduce the overall productivity of an economy (Barro 2000).

Two more approaches highlight a potential negative effect of inequality. The domestic market size approach emphasizes the relevance of the middle class and the risks of lower aggregate demand, derived from a higher proportion of population with lower purchasing power and the fact that lower income groups tend to have higher propensity to demand local products (Murphy et al. 1989; Todaro 1997).

The endogenous fertility approach highlights the link between higher inequality and higher fertility rates, which in turn reduce growth. In particular, this happens given that as the number of children per family increases, the average investment in education decreases (Barro 2000; Ehrhart 2009).

By contrast to the above-discussed mechanisms, according to classical and neoclassical theories an increase in inequality leads to higher aggregate savings, as there is greater propensity to save among the rich. Higher aggregate saving leads to higher levels of investment and growth (Kaldor 1956), this effect being lower the more open the economy is.

Finally, another two approaches have mixed predictions about the net effect of inequality. According to the political economy approach, either high inequality leads to higher redistributive pressure, which in turn may lead to economic distortions and disincentives (Alesina and Rodrik 1994; Persson and Tabellini 1994), or leads the rich to lobby to prevent efficient redistribution policies (e.g. public education) from being implemented (Saint-Paul and Verdier 1996; Acemoglu and Robinson 2008). ${ }^{5}$ These lobbying

\footnotetext{
5 Saint Paul and Verdier (1996) challenge the conventional political economy approach and argue that in fact unequal societies redistribute less and that this in turn is detrimental to growth. More recently, Woo (2011) has suggested a fiscal volatility channel for inequality to negatively influence growth.
} 
activities represent a waste of resources related to rent seeking and corruption and precisely characterize what several authors have highlighted as the fundamental adverse role of inequality in the current global crisis (Stiglitz 2009; Krugman 2012).

According to the credit-market imperfections approach, credit constrains reduce the capacity of many individuals to invest. This not only increases macroeconomic volatility (Aghion et al. 1999), it also reduces average investment - especially in human capital (Galor and Zeira 1993). Both aspects reduce longrun growth. However, under large set-up costs or investment indivisibilities higher inequality can allow some individuals to reach the necessary wealth to invest, leading to greater aggregate investment (Aghion et al. 1999).

The above transmission channels have all been extensively described in the related literature. Nevertheless, given data constraints and the difficult task of separately measuring each channel, few studies have attempted to empirically and independently assess each of the transmission channels. Indeed, despite extensive evidence on the overall impact of inequality on growth, a comprehensive empirical analysis and joint examination of the several transmission channels is still missing in the literature. Those studies that have tried to analyse the dynamics of the transmissions channels have usually focused on a single theoretical approach. The aim of these studies is to first see the relationship between inequality and a given variable, as a proxy for the channel under analysis, to then see the effect of this variable on growth (or variables that we know are relevant for growth, like investment). Appendix A lists the main papers providing empirical evidence for the different channels, the variables they use as proxy for the channel, and the effect they find either on growth or investment.

Seminal works are Perotti (1994, 1996), Persson and Tabellini (1994) and Alesina and Perotti (1996). While the latter provides evidence on the negative role of socio-political instability (using several variables for social unrest), Perotti (1994) tests two other approaches, namely the capital-market imperfections approach, using loan-to-value payment for mortgages as variable, and the political economy approach, using the share of government transfers in GDP as a proxy for redistribution. However, none of these papers considers the different channels in a single model. In a similar fashion to Alesina and Perotti, later studies have focused on liberties, institutions and the quality of property rights as the main transmission channel within the socio-political instability approach (Svensson 1998; Keefer and Knack 2002). Concerning the 
role of the domestic market, on the one hand Falkinger and Zweimüller (1997) consider product diversity, while on the other hand Keefer and Knack (2002) consider variables related to population, aggregate GDP and openness. In both, results are not conclusively supportive of the domestic-market approach. However, Davis (2008) has revalidated the relevance of scale effects, particularly in developing countries, and several other authors have provided evidence of the relevance of the size of the middle class (Easterly 2001; Partridge 2005). Regarding the endogenous fertility approach, several studies provide evidence on the positive link between inequality and fertility rates (Perotti 1996; Koo and Dennis 1999; Kremer and Chen 2002) and a negative effect of fertility rates on growth (Barro 2000).6 Persson and Tabellini (1994) focused on the political economy approach, by considering welfare transfers on a small sample of 13 OECD countries for which data were available, to find non-significant results about the prediction that inequality increases redistribution, and that redistribution reduces growth. In fact, as noted before, other authors support a different relationship between inequalities and redistributive polices. Easterly (2007) tests the institutional mechanism. Using geographical variables, in particular the exogenous suitability of land for wheat versus sugarcane - as proxy for factor endowment differentials across countries - and the proportion of population in tropical areas, he confirms a negative effect of inequality on long-run development.

Finally, although there is evidence of a growth-enhancing effect expected to be related to incentives for capital accumulation (Galor 2009) and for innovation, to incentives to work hard and take risks (World Bank 2006), and to agglomeration economies (Fallah and Partridge 2007; Castells-Quintana and Royuela 2014), we have not found in any paper any explicit assessment of the transmission channels related to this positive effect.

Unifying the classical and modern perspectives, Galor and Moav (2004) suggest a changing relationship between inequality and growth depending on the process of development. Inequality is growth enhancing in early stages of development, adverse afterwards in that process, and irrelevant in developed economies. ${ }^{7}$ Papers such as Barro (2000), Chen (2003), Voitchovsky (2005), and Castells-Quintana and

\footnotetext{
${ }^{6}$ Yet, even controlling for fertility, Barro finds a negative effect of inequality in poor countries and a positive effect in rich countries. 7 In particular, in early stages of development, when physical capital accumulation is the prime engine for growth, inequality can enhance the process of development by channelling resources towards individuals whose marginal propensity to save is higher, allowing for higher levels of investment. In later stages of development, however, when human capital accumulation becomes the prime engine for growth, and given credit constraints, higher inequality leads to a lower spread of education among individuals, handicapping the process of development due to diminishing returns of human capital. Finally, as capital markets develop and credit constrains are relaxed, inequality becomes irrelevant.
} 
Royuela (2014) provide evidence that inequality can have both negative and positive effects on economic growth, depending on the circumstances of the country. Nevertheless, in these papers the two opposing effects are not empirically related to any of the different channels through which inequality might affect growth, neither is there evidence of both effects happening simultaneously. ${ }^{8}$

Summing up, although theoretically the relationship between inequality and growth works through different channels, with inequality potentially having at the same time a positive and a negative effect on economic growth, empirical evidence in this sense is still scarce. To the best of our knowledge, only Marrero and Rodriguez (2013), using U.S. states panel data, find opposing effects for two components of inequality. However, they do not consider empirically the different channels through which inequality affects growth. We contribute to the literature by providing further evidence of these two different components of inequality having opposing effects on a single model of long-run economic growth, considering the multiple transmission channels and using cross-country, rather than state-level, data.

\section{EMPIRICAL APPROACH}

Because the focus is on the long-run effects of income inequality, we followed the literature on the determinants of cross-country differences on long-run economic growth. This literature tends to rely on OLS "Barro regressions", using a cross-section data of growth rates and initial values of the explanatory variables. Results are interpreted as measuring the long-run effects of those variables. In the empirical literature on the effects of inequality on economic growth, the majority of cross sectional studies has found a negative coefficient (Dominicis et al. 2008). However, Binder and Georgiadis (2011) list up to four basic problems associated with these regressions: all cross country heterogeneities are assumed to be fully captured by the control variables; they are subject to endogeneity bias; there is no clear distinction between short and long-run dynamics; and nonlinearities are not considered. All these arguments have been approached in the literature. The classification of countries and the introduction of interactions is a first strategy to deal with problems of heterogeneities and nonlinearities (Brock and Durlauf 2001; Durlauf et al. 2005). Another strategy is the use of panel data sets and techniques. When panel data sets are considered,

\footnotetext{
${ }^{8}$ Voitchovsky (2005) does find parallel positive and negative effects in a single model by using different parts of the income distribution; inequality at the top end of the distribution is positively associated with growth, while inequality lower down the distribution is negatively related to subsequent growth. However, the paper acknowledges that its empirical analysis "is not very informative regarding the different channels through which inequality might affect income."
} 
the negative effect disappears and even becomes positive once fixed effects or GMM methods are used. Nonetheless Partridge (2005) has criticised the use of fixed effects methods for the analysis the relationship between inequality and growth, as inequality is a highly persistent variable over time. Similarly, Barro (2000) maintains that fixed effects estimates exacerbate the bias due to measurement error. In this paper we have taken the above into account integrating into a cross section framework both the positive and negative effects of inequality on economic growth focusing on long-run dynamics (as we average growth over 37 years). In particular, we followed Sala-i-Martin et al.'s (2004) analysis on economic growth using crosssectional data.

We set a neoclassical econometric model of economic growth (equation (1)) where growth is our dependent variable, reflecting cumulative annual average GDP growth rate (in per capita terms), $I_{i 0}$ is income inequality, and $X_{i}$ is a list of control variables, including the initial income, $y_{i 0}$ :

$$
\text { growth }_{i}=c+X_{i} \boldsymbol{\Gamma}+\beta I_{i 0}+u_{1 i}
$$

OLS regressions are likely to underestimate the negative effect of inequality, and this could be indeed because of a co-occurring positive effect (Easterly 2007). In fact, reduced form estimations for the effect of inequality on growth are likely to pick up different effects at the same time (Bourguignon 1996), related to the above-discussed transmission channels. A common strategy in the empirical literature reviewed has been the use of intermediate variables as proxies for the channel under analysis. In parallel, taking into account endogeneity concerns on the effect of inequality on growth and the existence of two differentiated components of inequality, a second approach has been to isolate one of those components using specific instruments for inequality. Therefore, both strategies - intermediate variables and instruments - rely on the use of alternative information to capture a particular relationship between inequality and longrun growth. In the first strategy each channel is considered independently and no attempt is made to examine all of them in a single growth model. In fact, as we have seen, few papers consider empirically more than a single channel. Similarly, in the second strategy, while the negative effect of inequality has been identified with exogenous instruments (Easterly 2007), that has not been the case with the positive effect. Consequently, the use of alternative information has only been capable to identify the negative impact of 
inequality on economic growth. This is reasonable indeed as the positive association refers to market dynamics intrinsic to the growth process itself, which makes it difficult (if not impossible) to find exogenous variables for the identification process.

Building on both strategies, and assuming the problem of identification for the positive impact of inequality on economic growth, our goal is to disentangle, in a single model, the two possible relationships between inequality and long-run economic growth. In order to do that, we considered several variables that the literature has proposed as associated with the different transmission channels, to capture the negative effect of inequality on growth. Once the negative impact of inequality on economic growth was identified, we isolated the positive association between the two variables.

Hence, following the literature, we considered inequality in equation (1) as endogenous, i.e. correlated with the disturbance term, $u_{1 i}$. One solution for dealing with endogeneity is to apply the socalled Control Function Approach. Like instrumental variables (2SLS), this procedure uses instruments to break the correlation between endogenous explanatory variables and unobservable variables affecting the response. In linear models with one endogenous regressor, CFA yields identical results to those obtained with 2SLS. CFA yields consistent parameter estimates if instruments are valid (see Imbens and Wooldridge 2009 and Wooldridge 2010).

Following Wooldridge's (2010) formalization of the CFA, we considered a list of instruments for inequality, $Z$, that are exogenous in model (1):

$$
E\left(Z^{\prime} u_{1}\right)=0
$$

where $X$ in model (1) is a strict subset of $Z$. As in 2SLS, we considered the reduced form for inequality as:

$$
\begin{aligned}
& I=Z \boldsymbol{\Phi}+v_{2} \\
& E\left(Z^{\prime} v_{2}\right)=0
\end{aligned}
$$

Since $u_{1}$ is uncorrelated with $Z$, it turns out that $I$ is endogenous in (1) if and only if $E\left(u_{1} v_{2}\right) \neq 0$. The linear projection of $u_{1}$ onto $v_{2}$ in error form is:

$$
u_{1}=\rho_{1} v_{2}+e_{1}
$$

Since both $u_{1}$ and $v_{2}$ are orthogonal to $Z$, then $E\left(Z^{\prime} e_{1}\right)=0$, and $I$ is exogenous if and only if $\rho_{1}=0$. Plugging equation (5) into equation (1) transforms our growth equation into: 


$$
\text { growth }=c+X \Gamma+\beta I_{0}+\rho_{1} v_{2}+e_{1}
$$

where, by construction, $e_{1}$ is uncorrelated with $X, I$ and $v_{2}$. As we cannot observe $v_{2}$, the solution under the CFA is to estimate $\hat{v}_{2}$ - the residual from an OLS regression of equation (3). Replacing $v_{2}$ with $\hat{v}_{2}$ in (6) and estimating again by OLS yields consistent estimates for $\boldsymbol{\Gamma}, \beta$ and $\rho_{1}$. The parameter $\rho_{1}$ in (6) will capture the bias that would affect $\beta$ if we did not control for $\hat{v}_{2}$, allowing us to see the sign and magnitude of that bias.

Now, if we assume that our instrument set - $Z$ in equation (2) - is only able to capture a negative form of inequality, the remaining unexplained variance of inequality, including its positive form, is captured by $v_{2}$. In other words, as far as we can capture the negative component of inequality by $Z$, the remaining variance of inequality will most likely be an approximation of its positive component. Consequently, the parameter $\rho_{1}$ in an OLS estimation of equation (6), once the original values of $I$ and the estimations of $v_{2}$, namely $\hat{v}_{2}$, are included, can help us to identify the (potential) positive association between inequality and long-run economic growth.

Alternatively, we could consider inequality as $I=Z \Pi_{1}+W \Pi_{2}+\omega_{2}$, where only the negative component can be captured with instrumental variables $(Z)$, while the positive component can only be captured through covariates, $W$, that are correlated with $u_{1}$. Hence, the residual of the linear projection of $I$ on $Z, v_{2}$, would equal $W \Pi_{2}+\omega_{2}$, and the linear projection of $u_{1}$ onto $v_{2}$ in error form would be $u_{1}=$ $\rho_{1}\left(W \Pi_{2}+\omega_{2}\right)+e_{1}$. Consequently, the remaining estimated component $\hat{v}_{2}$ in our growth equation would include $W \Pi_{2}$ plus any unexplained variance, $\omega_{2}$. In this case $\beta$ would consistently estimate the negative influence of inequality on economic growth. It can happen, though, that some mechanisms of inequality are at the same time related to their positive and to their negative associations with growth, as suggested in the literature, and consequently $E\left(Z^{\prime} W\right) \neq 0$. In such case, the estimation of $\boldsymbol{\Phi}$ in (3) would not equal $\boldsymbol{\Pi}_{\mathbf{1}}$, being the bias linked to $E\left(Z^{\prime} W\right)$. As a consequence our approach would be affected and we could expect a bias towards zero of both $\beta$ and $\rho_{1}$ in (6). Subsequently, we understand that the misspecification in (3) coming from not considering instruments of the positive channel of inequality, $W$, that could be correlated with the instruments of negative channels, $Z$, would be driving our estimates in (6) to be non-significant. 
Hence, if we find significant results for both $\beta$ and $\rho_{1}$, we will be able to say that they are downward bounded. ${ }^{9}$

\section{DATA}

As control variables in our growth model we used $\log p \operatorname{cg} d p$ - the initial level of per capita GDP (in log), life_exp - the life expectancy at birth, $p 60$ - the primary enrolment rate, yrsopen - the number of years the economy has been open between 1950 and 1994, primary_exports - the fraction of primary exports in total exports, and mining - the fraction of GDP in mining - to capture natural endowments. ${ }^{10}$ The data, aside that for income inequality, comes from Sala-i-Martin et al. (2004), the Penn World Table (PWT), and the World Bank Development Indicators database. Income inequality is measured by the Gini coefficient, and we relied on Gruen and Klasen (2008). ${ }^{11} \mathrm{~A}$ table with the variables used and their sources is annexed as Appendix B. We used data as close to 1970 as possible to explain average growth rates between 1970-2007 in a sample of 51 countries (a list of which is also annexed as Appendix C). ${ }^{12}$

Table 1 presents descriptive statistics for the variables used in the growth equation, while Table 2 presents correlations among the variables. Growth is positively correlated with initial values of life_exp, $p 60$ and yrsopen. By contrast, is negatively correlated with initial values of log_pcgdp, primary_exports, mining and inequality. In fact, the highest negative correlation (-0.371) is of growth with inequality. Regarding inequality and the controls, inequality is positively correlated with mining and primary_exports and negatively correlated with all the other variables.

Table 1: Descriptive statistics: variables in growth equation

\begin{tabular}{l|l|ll}
\hline Mean & Std. Dev. & Maximum Minimum
\end{tabular}

\footnotetext{
9 The use of residual variation in recursive estimation to disentangle opposing dynamics has already been used in the macroeconomics literature. As far as we know, however, it is the first time it has been used for inequality.

${ }^{10}$ Out of 67 possible explanatory variables, Sala-i-Martin et al. (2004) found 18 that were significantly related to long-run growth during 1960-1996. Results suggest that main determinants for growth include initial levels of per capita GDP - the neoclassical idea of conditional convergence - and variables for natural resource endowments, physical and human capital accumulation, macroeconomic stability. Productive specialization also seems to negatively affect growth, with a negative and significant effect found for the fraction of primary exports in total exports.

${ }^{11}$ These coefficients were adjusted from the WIID database for different possible objects of measure and related to households or families and for the entire population, allowing us to address concerns about international comparability of inequality data. These adjusted coefficients have previously been used by us as well as by other authors (e.g. Atkinson and Brandolini 2010). We relied on income, rather than land or wealth, inequality, because it is income distribution that possibly reflects two distinct sources of inequality, namely inequality of opportunities and inequality of returns, which influence economic growth in opposite directions (Neves and Silva 2013).

12 The selected countries are those for which reliable data for all the variables used here has been found. The sample includes major countries from all world regions.
} 


\begin{tabular}{lc|c|cc}
\hline growth & 2.222 & 1.515 & -0.903 & 7.620 \\
inequality & 44.108 & 9.377 & 26.400 & 62.400 \\
\hline log_pcgdp & 8.381 & 1.010 & 6.332 & 9.891 \\
life_exp & 60.206 & 10.586 & 40.365 & 74.649 \\
p60 & 0.799 & 0.237 & 0.100 & 1.000 \\
yrsopen & 0.447 & 0.357 & 0.000 & 1.000 \\
primary_exports & 0.104 & 0.097 & 0.009 & 0.555 \\
mining & 0.040 & 0.047 & 0.000 & 0.208 \\
\hline
\end{tabular}

Table 2. Correlations: variables growth equation

\begin{tabular}{|c|c|c|c|c|c|c|c|}
\hline & growth & inequality & $\log \_p c g d p$ & life_exp & p60 & yrsopen & primary_exports \\
\hline growth & 1.000 & & & & & & \\
\hline inequality & -0.371 & 1.000 & & & & & \\
\hline log_pcgdp & -0.079 & -0.301 & 1.000 & & & & \\
\hline life_exp & 0.302 & -0.498 & 0.854 & 1.000 & & & \\
\hline p60 & 0.375 & -0.321 & 0.703 & 0.837 & 1.000 & & \\
\hline yrsopen & 0.264 & -0.337 & 0.696 & 0.707 & 0.629 & 1.000 & \\
\hline primary_exports & -0.345 & 0.239 & -0.177 & -0.264 & -0.203 & -0.120 & 1.000 \\
\hline mining & -0.199 & 0.259 & -0.253 & -0.402 & -0.254 & -0.228 & 0.509 \\
\hline
\end{tabular}

No. of observations included: 51

Additionally, we looked for variables related to inequality that we could use to identify each of the transmission channels that give rise to an effect on long-run economic growth. As our goal is to use these variables to disentangle different dynamics in the relationship between initial inequality and subsequent growth, we considered data as close to 1970 as possible (and with controls in the growth equation). To capture the institutional mechanism, and following Easterly (2007), we considered geographical variables: the exogenous suitability of land for wheat versus sugarcane - as proxy for factor endowment differentials across countries - and the proportion of population in tropical areas. We added the proportion of mountainous lands, as it seems to have a high and significant explanatory power for inequality, as we discuss below. Using geographical variables has the additional econometric advantage of allowing us to capture exogenous variation that helps us identify the effect of (structural) inequality. ${ }^{13}$ For Socio-Political Instability (SPI) we considered variables related to social unrest and violence, following Alesina and Perotti (1996). We used a parsimonious strategy and selected, among several variables positively correlated with inequality and

13 As in Easterly (2007), the considered geographical determinants appear as highly correlated with institutional variables. However, introducing institutional variables directly is challenging given that institutions are expected to be endogenous to economic performance. 
negatively with growth, three variables that yielded the highest R-square in a regression on inequality. ${ }^{14}$ For Domestic Market size and the role of the middle class (DM) we used aggregate GDP and the share of the third quintile in the income distribution. Using openness as one of the controls in the growth equation already captures the role played by foreign markets in the total market size. For the role of Fertility decisions (FER) we considered population growth rates, infant mortality rates, and the proportion of family farms, all highly correlated with fertility rates and inequality levels. ${ }^{15}$ For redistributive policies, as one main focus of the Political Economy (PE) approach, we used average government spending and average expenditure on education, both as share of GDP. Regarding the Credit Market Imperfections (CMI) approach, we considered access to sound money and patents, as proxy for innovation. Table 3 presents descriptive statistics for all the different variables considered and their correlation with inequality.

\section{ESTIMATION AND RESULTS}

We implemented our empirical strategy by recursive estimation. Hence, in a first equation we relate income inequality to different variables according to transmission channel (as in equation 3). From this first estimation we generated for each set of variables, an estimated residual term, $\hat{v}_{2}$, capturing the unexplained variance in inequality. The aim here is simply to decompose the variance in inequality. In a second equation, and again for each set of variables, we introduced inequality and the estimated residual from the first equation, along with control variables, in order to estimate our model of long-run economic growth. By introducing both terms, i.e. inequality and the estimated residual, we were able to assess two differentiated effects on economic growth. By using different sets of variables, we could analyse which factors needed to be controlled for our residual to capture a long-run growth-enhancing component of inequality. This is something that is not done in panel data analysis, which suggests a positive effect of inequality on growth.

Table 3. Descriptive statistics: variables inequality equation

\footnotetext{
${ }^{14}$ We also considered several other variables for social unrest and violence as robustness checks in the estimations described in section 4. Aside from social unrest and violence, other authors have considered variables related to liberties, rights and institutions. However, data for these variables are only available from the 80 s and are expected to by highly affected by economic performance. We therefore restricted our analyses to the selected variables, which are some of the most commonly used in the literature and helped to reduce endogeneity.

15 When we regressed inequality on our controls, fertility rates did not add significant explanatory power, and their use as a valid instrument for inequality was rejected by the instrument tests implemented.
} 


\begin{tabular}{|c|c|c|c|c|c|}
\hline Considered variables & Mean & Std. Dev. & Min & Max & $\begin{array}{l}\text { Corr. with } \\
\text { Inequality }\end{array}$ \\
\hline \multicolumn{6}{|c|}{ Geography-Institutions } \\
\hline wheat_sugar & 0.079 & 0.182 & -0.393 & 0.442 & -0.625 \\
\hline troppop & 0.197 & 0.315 & 0.000 & 1.000 & 0.339 \\
\hline mount & 17.587 & 18.651 & 0.000 & 73.700 & 0.412 \\
\hline \multicolumn{6}{|c|}{ Socio-Political Instability (SPI) } \\
\hline assassp2 & 0.005 & 0.021 & 0.000 & 0.138 & 0.254 \\
\hline death & 12.102 & 4.365 & 5.678 & 23.500 & 0.173 \\
\hline wardum & 0.392 & 0.493 & 0.000 & 1.000 & 0.265 \\
\hline \multicolumn{6}{|l|}{ Domestic Market } \\
\hline Q3 & 13.979 & 3.187 & 7.700 & 18.720 & -0.792 \\
\hline $\log G D P 1970$ & 10.470 & 0.780 & 8.740 & 12.573 & -0.412 \\
\hline \multicolumn{6}{|l|}{ Fertility } \\
\hline pop_growth & 1.969 & 1.068 & -0.584 & 4.458 & 0.512 \\
\hline mortality & 76.691 & 51.507 & 11.200 & 193.000 & 0.460 \\
\hline \multicolumn{6}{|l|}{ Political Economy } \\
\hline $\operatorname{kg} 702007$ & 8.593 & 4.264 & 2.221 & 20.918 & 0.020 \\
\hline exp_edu & 15.070 & 4.403 & 6.187 & 24.478 & 0.358 \\
\hline \multicolumn{6}{|c|}{ Credit Market Imperfections (CMI) } \\
\hline fi_sm & 7.017 & 1.608 & 2.518 & 9.647 & -0.029 \\
\hline innovation & 74.704 & 124.992 & 0.000 & 539.986 & -0.492 \\
\hline familyf & 46.843 & 25.808 & 2.000 & 94.000 & -0.435 \\
\hline
\end{tabular}

Table 4 presents the results from estimating equation (3), our inequality equation, including controls from the growth equation. We report standardized (beta) coefficients and Shea's Partial R-square to measure the relevance of the considered variables excluded from the growth equation. All channels report significant parameters. The channel with the highest partial R-square (0.489) corresponds to the geography-institutions (column 1). These variables are time-invariant factors that are cancelled out in the panel data analysis with fixed effects or first differences. This could explain why a positive effect of inequality is found in this type of analysis. The proportion of mountainous land deserves special attention. Although not considered before in the literature as an instrument for inequality, it has a high correlation with inequality and remains highly significant even when controlling for other proxies for structural inequality. Finally, in column (7) we considered all factors associated by the empirical literature with a negative effect of inequality, and consequently we excluded the variables associated with the political economy and credit market imperfections approaches, which report significant parameters for the positive side of these two channels. The exclusion of these variables is reinforced by the performed Hansen tests (as we further explain below). All these factors explain about 80 per cent of the variance in inequality.

Table 4: Results for the inequality equation 


\begin{tabular}{|c|c|c|c|c|c|c|c|}
\hline & 1 & 2 & 3 & 4 & 5 & 6 & 7 \\
\hline & $\begin{array}{l}\text { Geography- } \\
\text { Institutions }\end{array}$ & SPI & $\begin{array}{c}\text { Domestic } \\
\text { Market }\end{array}$ & Fertility & $\begin{array}{c}\text { Political } \\
\text { Economy }\end{array}$ & CMI & \\
\hline wheat_sugar & $-0.481 * * *$ & & & & & & -0.124 \\
\hline troppop & 0.123 & & & & & & -0.101 \\
\hline mount & $0.298 * * *$ & & & & & & $0.249 * *$ \\
\hline assassp2 & & 0.187 *** & & & & & 0.196 *** \\
\hline death & & $-0.956 * * *$ & & & & & $-0.566 * *$ \\
\hline wardum & & 0.024 & & & & & -0.054 \\
\hline Q3 & & & $-0.727 * * *$ & & & & $-0.518 * * *$ \\
\hline $\log G D P 1970$ & & & -0.164 & & & & -0.016 \\
\hline pop_growth & & & & $0.400 *$ & & & -0.170 \\
\hline mortality & & & & -0.135 & & & -0.089 \\
\hline familyf & & & & $-0.286 *$ & & & -0.038 \\
\hline kg702007 & & & & & 0.044 & & \\
\hline exp_edu & & & & & $0.345 * *$ & & \\
\hline fi_sm & & & & & & 0.035 & \\
\hline innovation & & & & & & $-0.453^{* * *}$ & \\
\hline $\mathrm{R}^{2}$ & 0.670 & 0.612 & 0.666 & 0.843 & 0.447 & 0.454 & 0.825 \\
\hline $\begin{array}{l}\text { Shea's Partial } \\
\mathrm{R}^{2}\end{array}$ & 0.489 & 0.399 & 0.483 & 0.199 & 0.143 & 0.155 & 0.728 \\
\hline
\end{tabular}

Notes: First-stage estimations using robust standard errors and small-sample correction. ${ }^{*} \mathrm{p}<0.10,{ }^{*} \mathrm{p}<0.05$, $* * * \mathrm{p}<0.01$. OLS coefficients have been standardized to ease comparability. Controls from the growth equation (log_pcgdp, life_exp, p60, yrsopen, primary_exports and mining) are also included. Shea's partial $\mathrm{R}^{2}$ measures the relevance of the excluded instruments (i.e. those not included in the growth equation). Column 7 excludes instruments for PE and CMI channels, rejected by the Hansen test.

Before we assessed two components of inequality in the growth equation, we tested to what extent they indeed captured negative and positive dynamics in the growth process, based on the theory revised in section II. One simple and straightforward way is to see how the two components correlate with long-run growth, as well as with physical and human capital accumulation, innovation and institutional quality. On the one hand, our estimated inequality using all factor considered in column 7 of Table 4 has a significant negative correlation with growth, -0.462 , as well as with the average investment during the whole period $(k i),-0.247$, and with the total average years of schooling in 2005 (schooling), -0.429 . The correlation with innovation and institutional quality (icrg_qog) are also negative, -0.517 and -0.578 , respectively. On the other hand, our second component (the remaining variance in inequality) has a positive correlation with growth, 0.117, as well as with physical capital accumulation, 0.191 . Figure 1 plots our two orthogonal components and their relationship with long-run growth. Both components have been standardized to split the sample of countries in four quadrants. It can be seen that countries with lower estimated negative inequality had higher growth rates (represented with larger bubbles in the graph). Furthermore, the highest average growth rates were found in the top left quadrant of the figure. In this quadrant we find countries with low estimated 
negative inequality but a high estimated residual (our positive component); e.g. Denmark, Hungary, Ireland, South Korea and the United States. By contrast, the lowest average growth rates were found in countries with high estimated negative inequality but a low estimated residual (the bottom right quadrant, including mostly Latin American countries like Peru and El Salvador, but also other countries like Zambia and Cote d'Ivoire).

Figure 1: Two components of inequality and long-run growth

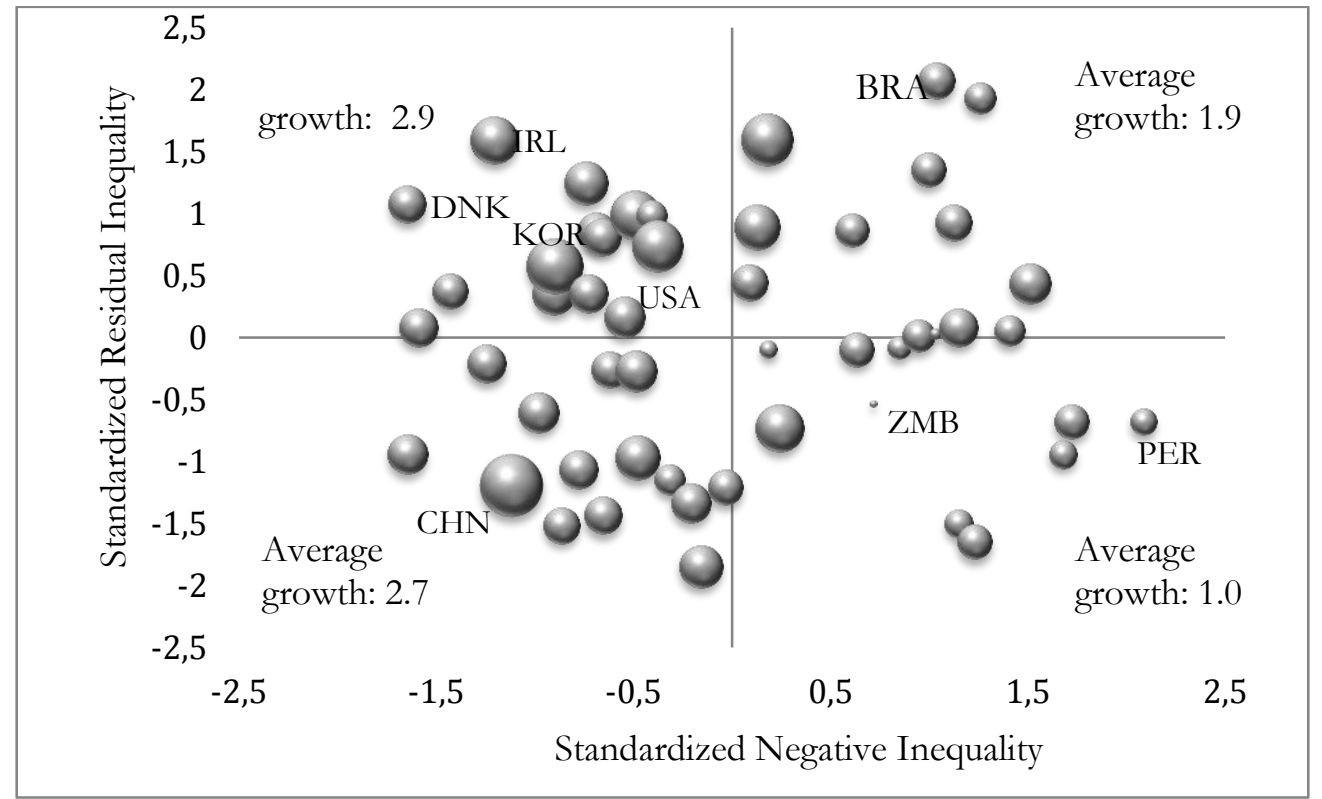

Notes: The size of each bubble is proportional to the long-run growth rates for each country.

Average growth figures reported represent averages calculated for the countries in each quadrant.

Table 5 presents results for the impact of inequality on long-run growth. Column 1 shows the results from the OLS estimation of model (1). Columns 2 to 6 present the results from our 2SRI (TwoStage Residual Inclusion) estimations, based on the CFA. ${ }^{16}$ 2SRI estimations were done using bootstrap standard errors to adjust for the generated regressor bias from the first equation. We report the KleibergenPaap LM test probability to check for under-identification, and the Hansen test probability to check for the validity of our approach. ${ }^{17}$ In each column we introduced as a further control in the growth equation the residual from the first set of estimation for inequality (as suggested by the CFA) for each considered channel.

\footnotetext{
${ }^{16}$ See Terza et al. (2008) for a good explanation of 2SRI and the requisites or its consistency.

${ }_{17}$ We tested for the relevance and validity of our approach in different ways. For relevance, we looked at the F statistic and the Partial-R-squared of the first regression, and performed under-identification tests. For validity we performed tests of overidentifying restrictions.
} 
Hence, column 2 only considers the geographical variables as instruments for inequality. Finally, column 8

includes all factors considered in column 7 of Table 4.

Tables 5: Results for the growth equation

\begin{tabular}{|c|c|c|c|c|c|c|c|c|}
\hline & 1 & 2 & 3 & 4 & 5 & 6 & 7 & 8 \\
\hline & \multirow[t]{2}{*}{ OLS } & 2SRI & 2SRI & 2SRI & 2SRI & 2SRI & 2SRI & 2SRI \\
\hline & & $\begin{array}{l}\text { Geography- } \\
\text { Institutions }\end{array}$ & $\begin{array}{c}\text { Socio- } \\
\text { Political } \\
\text { Instability }\end{array}$ & $\begin{array}{c}\text { Domestic } \\
\text { Market }\end{array}$ & Fertility & $\begin{array}{l}\text { Political } \\
\text { Economy }\end{array}$ & $\begin{array}{l}\text { Credit Market } \\
\text { Imperf. }\end{array}$ & \\
\hline Inequality & -0.015 & $-0.044 *$ & 0.0001 & $-0.061 * *$ & -0.037 & -0.015 & 0.002 & $-0.038 * *$ \\
\hline s.e. & -0.014 & 0.026 & 0.026 & 0.027 & 0.040 & 0.045 & 0.046 & 0.019 \\
\hline Resid & & 0.057 & -0.026 & $0.089 * *$ & 0.028 & -0.0009 & -0.020 & $0.083 * *$ \\
\hline s.e. & & 0.037 & 0.038 & 0.037 & 0.049 & 0.052 & 0.046 & 0.040 \\
\hline \multicolumn{9}{|l|}{ Controls: } \\
\hline $\log \_p c g d p$ & $-1.940 * * *$ & $-1.803^{* * *}$ & $-2.014 * * *$ & $-1.722 * * *$ & $-1.836 * * *$ & $-1.944 * * *$ & $-2.022 * * *$ & $-1.833^{* * *}$ \\
\hline life_exp & $0.118^{* * *}$ & $0.088^{*}$ & $0.134 * * *$ & 0.070 & 0.095 & $0.118^{* *}$ & $0.135^{* *}$ & $0.094 * *$ \\
\hline $\mathrm{p} 60^{-1}$ & $2.091 * *$ & $2.512^{* *}$ & $1.867^{*}$ & $2.756^{* *}$ & $2.410^{* *}$ & $2.080^{*}$ & 1.844 & $2.418^{* *}$ \\
\hline yrsopen & $1.450^{* *}$ & $1.374 * *$ & $1.490 * *$ & $1.331^{* *}$ & $1.393^{* *}$ & $1.452^{* *}$ & $1.494^{* *}$ & $1.391 * *$ \\
\hline primary_exports & $-4.657 * *$ & $-4.318^{* *}$ & $-4.834 * *$ & $-4.121 * *$ & $-4.400 * *$ & $-4.666^{*}$ & $-4.856^{* *}$ & $-4.393 * *$ \\
\hline mining & 4.477 & 4.061 & 4.698 & 3.820 & 4.162 & 4.488 & 4.721 & 4.154 \\
\hline Constant & $10.077 * * *$ & $11.690 * * *$ & $9.216^{* * *}$ & $12.627 * * *$ & $11.299 * * *$ & $10.033^{* * *}$ & $9.128 * *$ & $11.330^{* * *}$ \\
\hline Observations & 51 & 51 & 51 & 51 & 51 & 51 & 51 & 51 \\
\hline R squared & 0.672 & 0.692 & 0.676 & 0.721 & 0.675 & 0.672 & 0.674 & 0.706 \\
\hline $\mathrm{K}$-P p-value & & 0.001 & 0.008 & 0.000 & 0.028 & 0.024 & 0.004 & 0.028 \\
\hline Hansen p-value & & 0.771 & 0.406 & 0.364 & 0.178 & 0.068 & 0.039 & 0.368 \\
\hline \multicolumn{2}{|c|}{ Excluded instruments: } & $\begin{array}{l}\text { wheat- } \\
\text { sugar, } \\
\text { troppop } \\
\text { mount }\end{array}$ & $\begin{array}{l}\text { death } \\
\text { assassp2 } \\
\text { wardrum }\end{array}$ & $\begin{array}{l}\text { Q3 } \\
\text { logGDP19 } \\
70\end{array}$ & $\begin{array}{l}\text { pop_grow } \\
\text { th } \\
\text { mortality } \\
\text { familyf }\end{array}$ & $\begin{array}{l}\mathrm{kg} \\
\text { exp_edu }\end{array}$ & $\begin{array}{l}\text { fi_sm } \\
\text { innovation }\end{array}$ & $\begin{array}{l}\text { death } \\
\text { assassp2 } \\
\text { wardrum } \\
\text { Q3 } \\
\text { logGDP- } \\
\text { 1970, } \\
\text { pop- } \\
\text { growth, } \\
\text { mortality } \\
\text { familyf } \\
\text { wheat- } \\
\text { sugar, } \\
\text { troppop } \\
\text { mount }\end{array}$ \\
\hline
\end{tabular}

Notes: Estimations using bootstrap standard errors $\left(1,000\right.$ repetitions). ${ }^{*} \mathrm{p}<0.10,{ }^{* *} \mathrm{p}<0.05,{ }^{* * *} \mathrm{p}<0.01 . \mathrm{K}-\mathrm{P}$ is the KleibergenPaap LM statistic, which tests for the null hypothesis that the matrix of the reduced-form coefficients in the first-stage regression is under-identified. The Hansen J statistic tests the null hypothesis of instrument validity under the assumption of heteroscedasticity. Column 8 excludes instruments for PE and CMI channels, rejected by the Hansen test.

All controls have the expected sign in all estimations and their coefficients are all significant (except for that of mining). Results are consistent with conditional convergence, with a negative coefficient for initial per capita GDP of around 2 per cent - as in Sala-i-Martin 2004 - and higher human capital levels increasing long-run growth (i.e. a positive coefficient for life_exp and $p 60$ ). Openness is also positively 
associated with growth, while primary sector specialization is negatively so (i.e. a negative coefficient for primary_exports).

For inequality, the OLS estimation yields a negative, although non-significant, coefficient. As aforementioned, this could be the result of two significant effects cancelling each other out. ${ }^{18}$ When we further controlled for the two differentiated components, the coefficient for inequality became significant in some of the estimations. In particular, the set for geographical determinants of institutions (column 2), the sets of variables associated with domestic market (column 4), and all factors associated to a negative effect of inequality (column 8) yield in each case a significant and negative coefficient for inequality. In these estimations the coefficient for our forecasted residual, which captures the remaining variance in inequality not explained by the variables considered, is positive and significant (borderline significant in column 2). As we saw above any bias in our procedure for not considering the full set of variables would lower towards zero the estimates of both components. Consequently, the results are not only significant, but also downward-bounded, reinforcing our intuition.

These results support previous results of a negative effect of inequality, in particular related to the role of the size of the domestic market and the middle class, as to geographical factors defining structural inequality and bad institutional frameworks. Furthermore, our results support the idea of two differentiated components of inequality, associated with two different-signed effects. Nevertheless, these two parallel effects only become evident when the differentiated mechanisms for inequality are appropriately controlled for. Regarding the total impact of inequality, the OLS estimation in column 1 yields a net impact of inequality of -0.015. By contrast, controlling for two different components of inequality yields a negative effect of 0.038 and a positive effect of 0.083 . However, considering that our negative component of inequality captured around 80 per cent of the variance in inequality, with the residual capturing the remaining variance, the weighted average of the two can be approximated to -0.017 . This is close to the value reported in column 1 and results in previous studies, and an economically significant effect after considering the wide differences in the Gini coefficients among countries. The difference between the country with the highest inequality in

\footnotetext{
${ }^{18}$ We tested for the endogeneity of inequality. While Durbin and DWH tests reject the null hypothesis of no endogeneity, the Wooldridge test, which considers robust standard errors, did not (but with a p-value of 0.12 , still close to suggesting endogeneity).
} 
1970, Honduras, and the country with the lowest, Hungary, can represent a difference of half a point of average annual growth.

\section{Results by level of development}

Is there always a positive effect of inequality on economic growth? According to Galor and Moav (2004), as we have seen, the relationship between inequality and growth changes with the stage of development and is expected to be positive only in early stages, and non-significant in developed economies. ${ }^{19}$ However, Galor and Moav's analysis focuses on the role of credit market imperfections. However, we have seen that there are other channels at work. Thus, we can still have a positive effect of inequality at early stages of development, as suggested by Galor and Moav, but also a negative effect, as suggested by other approaches. We performed structural stability tests on our sample by differentiating countries based on whether they were OECD members in 1970 or not, as a proxy for stage of development. ${ }^{20}$ As the tests support the possibility of differentiated effects, in Table 6 we let the impact of our two components of inequality to vary for countries that were OECD members in 1970 and for countries that were non-members. ${ }^{21}$ All controls remained significant, except that for mining. Additionally, once we controlled for two components of inequality, the negative and positive effects of inequality are only significant in developing countries. For developed countries the two components still have coefficients with opposing signs, although they are nonsignificant (in line with Galor and Moav 2004).22

Table 6: Growth equation, by level of development

Dependent variable: growth

\begin{tabular}{lrc}
\hline & $\begin{array}{l}2 \text { SRI } \\
\text { coef. }\end{array}$ & s.e. \\
\hline INEQUALITY*OECD & -0.0339 & 0.033
\end{tabular}

\footnotetext{
${ }^{19}$ Indeed, the previously studied correlations of our two components of inequality with growth and capital accumulation become stronger if we consider separately the developing and the developed countries.

${ }^{20}$ In particular, we tested parameter heterogeneity for the coefficients for our two components of inequality based on the OECDnon-OECD dichotomy.

21 Thus, we expect to partly control for heterogeneity across countries.

${ }^{22}$ Chambers and Krause (2010) provide evidence of the second phase of Galor and Moav's (2004) hypothesis; in particular that in countries with low educational attainments, the negative effects of inequality increase with higher capital stocks.
} 


\begin{tabular}{lcc} 
INEQUALITY*nonOECD & $-0.0365^{*}$ & 0.022 \\
Resid*OECD & 0.0598 & 0.058 \\
Resid*nonOCDE & $0.0898^{*}$ & 0.048 \\
Controls: & & \\
log_pcgdp & $-1.8726^{* * *}$ & 0.380 \\
life_exp & $0.0941^{* *}$ & 0.046 \\
p60 & $2.4309^{*}$ & 1.294 \\
yrsopen & $1.4035^{* *}$ & 0.601 \\
primary_exports & $-4.3623^{* *}$ & 2.061 \\
mining & 4.1268 & 4.005 \\
Constant & $11.5439^{* * *}$ & 2.577 \\
\multicolumn{2}{c}{51} \\
\hline Observations & \multicolumn{2}{c}{0.707} \\
R squared & \multicolumn{2}{c}{} \\
\hline Notes: Estimations using bootstrap standard errors $(1,000$ \\
repetitions). ${ }^{*} \mathrm{p}<0.10,{ }^{* *} \mathrm{p}<0.05,{ }^{* * *}<0.01$ \\
\end{tabular}

\section{SENSITIVITY AND ROBUSTNESS CHECKS}

Because our procedure relies on the selection of variables to identify the transmission channels, a further check of our results was to use a different set of variables for each of the channels. For most channels this is complicated because of data scarcity. However, the role of the different channels, and in particular the existence of a positive and a negative effect of inequality, appeared robust to the selection of variables to capture these channels. For instance, to capture the idea of socio-political instability we also tried the variables considered by Alesina et al. (1996, political instability dataset), although at the expense of losing 4 observations due to data availability, and we were still able to find significant coefficients (one positive and one negative) for our two components of inequality (see estimation 1 in Table 7).

Additionally, we analysed the possibility of direct effects on economic growth that were not associated with inequality of some of the channels considered. In particular, the fertility mechanism is expected to have a direct and negative effect on long-run growth, associated with family decisions relevant for physical and human capital accumulation (Barro 2000), and in fact we discarded fertility rates as violating validity tests. We controlled for fertility rates directly in the growth equation (see estimation 2 in Table 7). The coefficient for fertility is negative and significant, as expected. However, even after controlling for fertility we found two significant effects of inequality on growth. Barro found a non-significant effect for inequality after controlling for fertility, but did not consider, as we did, further opposing and significant effects of inequality that could be cancelling each other out. 
As with fertility, we expanded our analysis to the consideration of the direct (disaggregated) role of the different transmission channels in the growth equation. We followed Alesina and Perotti (1996) and constructed an index as proxy for socio-political instability (SPI index), using the method of principal components analysis applied to several variables of social unrest. For the role of the domestic market we introduced the initial income (logGDP1970), capturing domestic market size, and to quantify the role of the middle class, we included the share of the third quintile in the income distribution $\left(Q^{3}\right)$. For redistributive policies we introduced the variable share of government consumption over GDP (kg), which captures government spending. Finally, we maintained fertility rates as a further control. The estimation 3 of Table 7 shows how our main result of two opposing effects associated with inequality holds even after the inclusion of direct effects on the growth equation.

Table 7: Robustness checks

Dependent variable: growth

\begin{tabular}{|c|c|c|c|c|c|c|}
\hline & \multicolumn{2}{|c|}{ 2SRI (1) } & \multicolumn{2}{|c|}{ 2SRI (2) } & \multicolumn{2}{|c|}{ 2SRI (3) } \\
\hline & Coef. & s.e. & Coef. & s.e. & Coef. & s.e. \\
\hline Inequality & $-0.0373^{* *}$ & 0.018 & $-0.0212^{*}$ & 0.009 & & \\
\hline Resid & $0.0797 * *$ & 0.033 & $0.0727 * * *$ & 0.015 & $0.0597 *$ & 0.031 \\
\hline fertility & & & $-0.8818^{* *}$ & 0.264 & $-0.8295^{* * *}$ & 0.307 \\
\hline SPI_index & & & & & -0.1488 & 0.168 \\
\hline $\log \overline{\mathrm{G} D P} 1970$ & & & & & 0.3503 & 0.248 \\
\hline Q3 & & & & & 0.0712 & 0.051 \\
\hline kg702007 & & & & & -0.0338 & 0.040 \\
\hline \multicolumn{7}{|l|}{ Controls: } \\
\hline $\log \_p c g d p$ & $-1.4518 * * *$ & 0.251 & $-1.9032^{* * *}$ & 0.366 & $-2.0890 * * *$ & 0.329 \\
\hline life_exp & $0.0701 *$ & 0.037 & 0.0400 & 0.064 & 0.0451 & 0.056 \\
\hline $\mathrm{p} 60^{-1}$ & $2.1799 * *$ & 0.829 & 0.7530 & 0.412 & 0.3046 & 1.202 \\
\hline yrsopen & $1.1894^{* *}$ & 0.455 & $0.8005^{*}$ & 0.360 & 0.6223 & 0.501 \\
\hline primary_exports & $-3.5561 * * *$ & 1.212 & -0.8232 & 1.147 & 0.7057 & 2.461 \\
\hline mining & 3.6833 & 3.014 & 4.4076 & 2.884 & 3.1386 & 2.998 \\
\hline Constant & $9.6529 * * *$ & 1.852 & $18.7118^{* * *}$ & 2.046 & $14.8024 * * *$ & 3.352 \\
\hline Observations & \multicolumn{2}{|l|}{47} & \multicolumn{2}{|c|}{51} & \multicolumn{2}{|c|}{51} \\
\hline $\mathrm{R}$ squared & \multicolumn{2}{|l|}{0.619} & \multicolumn{2}{|c|}{0.778} & \multicolumn{2}{|c|}{0.818} \\
\hline
\end{tabular}

\section{DISCUSSION AND CONCLUSIONS}


We introduce the use of the control function approach (CFA), traditionally used to address endogeneity concerns, to analyse the relationship between inequality and economic growth. The CFA has allowed us to track different transmission channels of the effects of inequality on long-run economic growth, by using alternative sets of variables. By considering the idea of two differentiated components of inequality (WDR 2006) and different proxies expected to relate to different transmission channels, we have empirically distinguished in a single model both negative and positive effects of inequality on long-run growth. Our results suggest, in line with the literature, that high inequality has indeed a negative effect on long-run growth. This effect seems associated with increasing social unrest and political instability, lower aggregate demand for local goods, higher fertility rates, and bad institutional development. However, our results also support the possibility of a long-run growth-enhancing component of inequality, and allow us to see the relevance of the mechanisms that need to be controlled for that positive effect of inequality to become empirically evident.

Results emphasize the complexity of the relationships between income distribution and economic growth. This complexity exists everywhere but is more intense in developing countries. In this manner, what is interesting is not whether inequality is harmful or beneficial for growth but rather to attain a satisfactory description of the dynamics of the relationship in these countries. In order to assess the impact of inequality on economic growth in a given country, one should focus on the dynamics of inequality. When inequality is associated with political instability and social unrest, rent-seeking and distortive policies, lower capacities for investments in human capital and a stagnant domestic market, it is mostly expected to harm long-run economic performance, as suggested by many authors. Accordingly, improving income distribution is expected to foster long-run economic growth, especially in low-income countries, where the levels of inequality are usually very high. However, some degree of inequality can also be good, as has been theoretically argued before in the literature and as empirically suggested in this study. A degree of inequality, when driven by market forces and related to hard work and growth-enhancing incentives, like risk taking, innovation, capital investments and agglomeration economies, can play a beneficial role for economic growth. The challenge for policy makers is to control structural inequality that reduces the country's capacities for economic development, while at the same time keeping in place those positive incentives that 
are also necessary for growth. To ease this task, a broader and deeper understanding of the dynamics behind the relationship between inequality and economic development will prove to be invaluable.

\section{REFERENCES}

Acemoglu, D. 2005. The form of property rights: Oligarchic vs. Democratic societies. MIT mimeo, April 2005.

Acemoglu, D. and Robinson, J. 1994. Persistence of power, elites and institutions. American Economic Review 98(1): 267293.

Alesina, A. and Rodrik, D. 1994. Distributive politics and economic growth. Quarterly Journal of Economics 109: 465-490.

Alesina, A., Özler, S., Roubini, N., and Swagel, P. 1996. Political instability and economic growth. Journal of Economic Growth 1: 189-211.

Alesina, A. and Perotti, R. 1996. Income distribution, political instability, and investment. European Economic Review 40, 1203-1228.

Aghion, P., Caroli, E. and García-Peñalosa, C. 1999. Inequality and Economic Growth: The Perspective of New Growth Theories. Journal of Economic Literature 37(4): 1615-1660.

Atkinson, A. and Brandolini, A. 2010. On analyzing the World Distribution of Income. World Bank Economic Review 24(1): $1-37$.

Barro, R. J. 2000. Inequality and growth in a panel of countries. Journal of Economic Growth 5: 5-32.

Barro, R. J., and Lee, J.W. 1993. International Comparisons of Educational Attainment. Journal of Monetary Economics 32: 363-394.

Binder, M. and Georgiadis, G. 2011 Determinants oh Human Development: Capturing the Role of Institutions. CESIFO Working Paper No. 3397.

Bourguignon, F. 1996. Equity and economic growth: permanent questions and changing answers? Document de trevail No 96-15, DELTA, Paris.

Bourguignon, F. and Verdier, T. 2000. Oligarchy, democracy, inequality and growth. Journal of Development Economics 2(62): 285-313.

Brescia, R. 2010. The cost of inequality: Social Distance, Predatory Conduct, and the Financial Crisis. NYU Annual Survey of American Law 66.

Brock, W. A. and Durlauf, S. 2001. Growth empirics and reality. World Bank Economic Review 15: 229-272.

Castells-Quintana, D. and Royuela, V. 2014. Agglomeration, Inequality and Economic Growth. Annals of Regional Science 52: 343-366.

Chambers, D. and Krause, A. 2010. Is the relationship between inequality and growth affected by physical and human capital accumulation? Journal of Economic Inequality 8: 153-172.

Chen, B. 2003. An inverted-U relationship between inequality and long-run growth. Economics Letters 78: $205-212$.

Clarke, G. 1995. More evidence on income distribution and growth. Journal of Development Economics 47: 403-427.

Collier, P. 2009. Beyond greed and grievance: feasibility and civil war. Oxford Economic Papers 61: 1-27.

Davis, L. 2008. Scale effects in growth: A role for institutions. Journal of Economic Behavior \& Organization 66: 403-419.

Davis, L. and Hopkins, M. 2011. The institutional foundations of inequality and growth. Journal of Development Studies 47(7): 977-997.

De Dominicis, L., Florax, R. and de Groot, H. 2008. A meta-analysis on the relationship between income inequality and economic growth. Scottish Journal of Political Economy 55(5): 654-682.

Durlauf, S., Johnson, P. and Temple, J. 2005. Growth Econometrics. In Philippe Aghion and Steven Durlauf (eds.), Handbook of Economic Growth, Elsevier: 255-677.

Ehrhart, C. 2009. The effects of inequality on growth: a survey of the theoretical and empirical literature. ECINEQ Working Paper Series 2009-107.

Easterly, W. 2001. The Middle Class Consensus and Economic Development. Journal of Economic Growth 6: $317-335$.

Easterly, W. 2007. Inequality does cause underdevelopment: insights from a new instrument. Journal of Development Economics 84: 755-776.

Engermann, S. and Sokoloff, K. 1997. Factor endowments, institutions, and differential paths of growth among new world economies: a view from economic historians of the United States. In: Haber, S. (Ed.), How Latin America Fell Behind. Stanford University Press, Stanford CA.

Falkinger, J. and Zweimüller, J. 1997. The impact of income inequality on product diversity and economic growth. Metroeconomica 48(3): 211-237.

Fallah, B. and Partridge, M. 2007. The elusive inequality-economic growth relationship: are there differences between cities and the countryside? Annals of Regional Science 41: 375-400.

Ferreira, F. 1999. Inequality and Economic Performance: A Brief Overview to Theories of Growth and Distribution. The World Bank, Washington, DC. 
Forbes, K. 2000. A reassessment of the relationship between inequality and growth. American Economic Review 90(4): 869-887.

Galor, O. 2009. Inequality and Economic Development: The Modern Perspective. Edward Elgar Publishing Ltd.

Galor, O. and Moav, O. 2004. From Physical to Human Capital Accumulation: Inequality and the Process of Development. Review of Economic Studies 71(4): 1001-1026.

Galor, O. and Zeira, J. 1993. Income distribution and macroeconomics. Review of Economic Studies 60(1): 35-52.

Gruen, C. and Klasen, S. 2008. Growth, inequality, and welfare: comparisons across time and space. Oxford Economic Papers 60: 212-236.

Hall, R. and Jones, Ch. 1999. Why do some countries produce so much more output per worker than others? Quarterly Journal of Economics 114(1): 83-116.

Heston, A. Summers, R. and Bettina, A. 2012. Penn World Table Version 7.1. Centre for International Comparisons of Production, Income and Prices. University of Pennsylvania.

Imbens, G.W. and Wooldridge, JM. 2009. New developments in Econometrics. Cemmap Lecture Notes 14.

Kaldor, N. 1956. Alternative Theories of Distribution. Review of Economic Studies 23(2): 83-100.

Keefer, P. and Knack, S. 2002. Polarization, politics and property rights: Links between inequality and growth. Public Choice 111: 127-154.

Kremer, M. and Chen, D. 2002. Income Distribution Dynamics with Endogenous Fertility. Journal of Economic Growth 7: 227-258.

Krugman, P. 2008. The return of depression economics and the crisis of 2008. Penguin. London.

Krugman, P. 2012. End this depression now! Norton. London.

Koo, L. and Dennis, B. 1999. Income inequality, fertility choice and economic growth: theory and evidence. Harvard Institute for International Development (HIID), Development Discussion Paper No 687.

Marrero G., and Rodriguez, J. 2013. Inequality of opportunity and growth. Journal of Development Economics 104: 107122.

Murphy, K. Shleifer A. and Vishny, R. 1989. Income distribution, market size, and industrialization. Quarterly Journal of Economics 104(3): 537-564.

Neves, P.C., and Silva, S.M.T. 2013. Survey article: Inequality and growth. Journal of Development Studies. DOI: 10.1080/00220388.2013.841885.

Partridge, M. 2005. Does income distribution affect U.S. state economic growth? Journal of Regional Science 45: 363-394.

Perotti, R. 1994. Income distribution and investment. European Economic Review 38: 827-835.

Perotti, R. 1996. Growth, income distribution and democracy: what the data say? Journal of Economic Growth 1: 149-187.

Persson, T. and Tabellini, G. 1994. Is Inequality Harmful for Growth? Theory and evidence. American Economic Review 84: 600-621.

PRS Group. 2012. International Country Risk Guide Researchers Dataset. Data Web Site: http:/ /hdl.handle.net/10864/10120 PRS Group.

Rajan, R. 2010. Fault Lines: How hidden fractures still threaten the world economy, Princeton University Press.

Sachs, J. and Warner, A. 1995 Economic reform and the process of economic integration. Brookings Papers on Economic Activity 1: 1-95.

Sachs, J. and Warner, A. 1997. Natural resource abundance and economic growth. CID at Harvard University. Data Web Site: www.cid.harvard.edu/ciddata.html.

Saint-Paul, G. and Verdier, T. 1996. Inequality, redistribution and growth: A challenge to the conventional political economy approach. European Economic Review 40: 719-728.

Sala-i-Martin, X., Doppelhofer, G. and Miller, R. 2004. Determinants of long-term growth: A Bayesian averaging of classical estimates (BACE) approach. American Economic Review 94(4): 813-835.

Sokoloff, K. and Engermann, S. 2000. Institutions, factor endowments, and paths of development in the New World. Journal of Economic Perspectives 14(3): 217-232.

Stiglitz, J. 2009. The global crisis, social protection and jobs. International Labour Review 148(1-2): 1-13.

Svensson, J. 1998. Investment, property rights and political instability: Theory and evidence. European Economic Review 42: 1317-1341.

Terza, J., Basu, A. and Rathouz, P. 2008. Two-Stage Residual Inclusion Estimation: Addressing Endogeneity in Health Econometric Modelling. Journal of Health Economics 27: 531-543.

Todaro, MP. 1997. Economic Development. London: Longman.

Voitchovsky, S. 2005. Does the profile of income inequality matter for economic growth? Distinguishing Between the Effects of Inequality in Different Parts of the Income Distribution. Journal of Economic Growth 10(3): 273-296.

Woo, J. 2011. Growth, income distribution, and fiscal policy volatility. Journal of Development Economics 96(2): 289-313.

Wooldridge, JM. 2010. Econometric Analysis of Cross-Section and Panel Data (Second Edition). MIT Press: Cambridge, MA.

World Bank. 2006. Equity and Development, World Development Report 2006. World Bank, Washington DC. 
APPENDIX A: Empirical Evidence on the channels: channels considered, variables used and main result

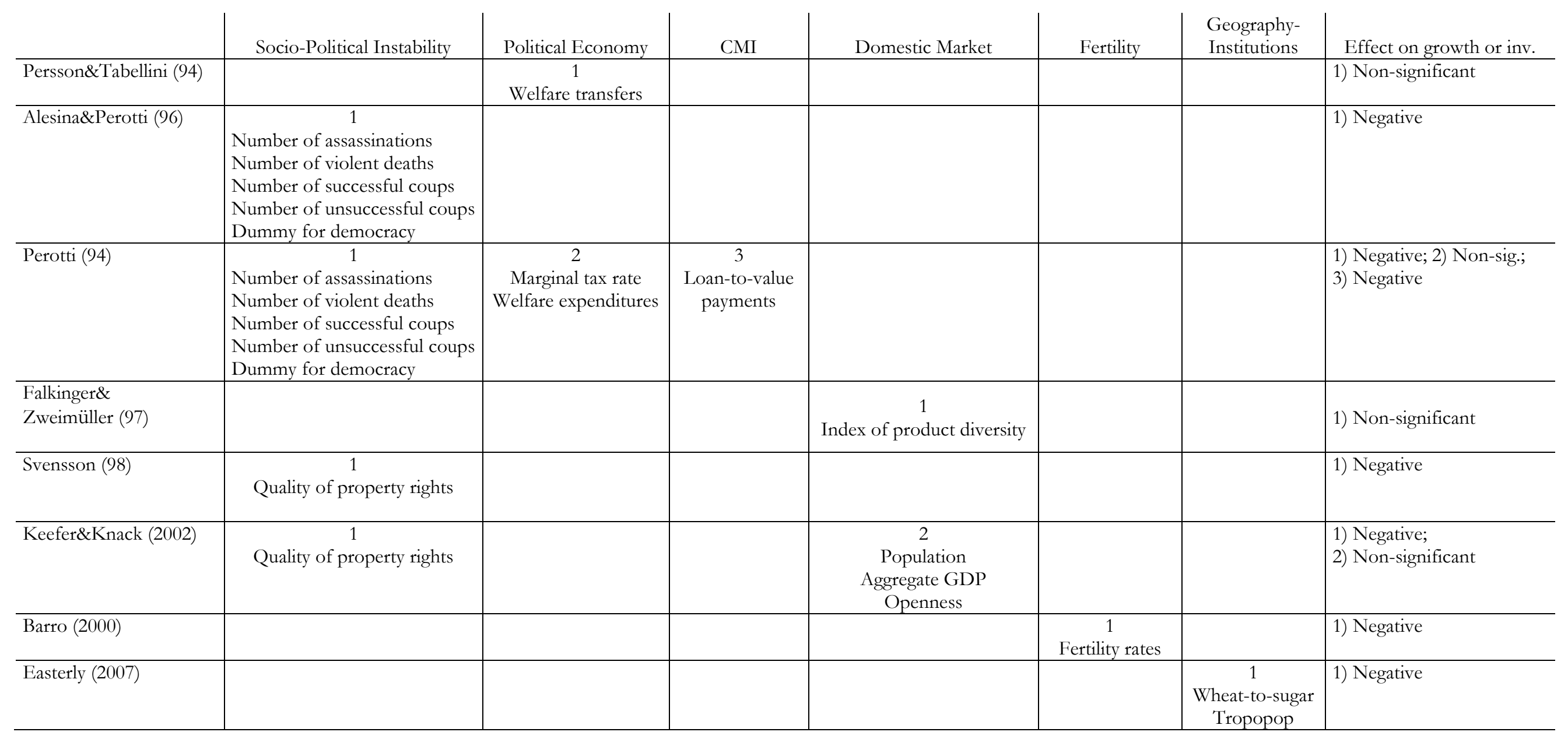


APPENDIX B: Variables used:

\begin{tabular}{|c|c|c|}
\hline Growth model & Description & Source \\
\hline $\begin{array}{l}\text { growth } \\
\text { inequality }\end{array}$ & $\begin{array}{c}\text { Cumulative annual average per capita GDP growth rate } \\
\text { Gini coefficient. } 1970\end{array}$ & $\begin{array}{c}\text { Constructed with data from PWT (Heston et al. 2012), using } \\
\text { real GDP chain data (rgdpch) } \\
\text { Gruen and Klasen (2008) }\end{array}$ \\
\hline $\log \_p c g d p$ & Per capita GDP (in logs) & $\begin{array}{c}\text { Constructed with data from PWT (Heston et al. 2012), using } \\
\text { real GDP chain data (rgdpch) }\end{array}$ \\
\hline life_exp & Life Expectancy at birth, total years. 1970 & World Bank \\
\hline p60 & Primary enrolment rate. 1960 & Sala-i-Martin et al. (2004). From Barro and Lee (1993) \\
\hline yrsopen & $\begin{array}{c}\text { Number of years the economy has been open } \\
\text { between } 1950 \text { and } 1994 .\end{array}$ & Sala-i-Martin et al. (2004). From Sachs and Warner (1995) \\
\hline primary_exports & Fraction of primary exports in total exports. 1970 & Sala-i-Martin et al. (2004). From Sachs and Warner (1997) \\
\hline mining & Fraction of GDP in mining. 1970 & Sala-i-Martin et al. (2004). From Hall and Jones (1999) \\
\hline \multicolumn{3}{|l|}{ Inequality Model } \\
\hline assassp2 & Number of political assassinations. & Sala-i-Martin (2004). From Barro and Lee (1993) \\
\hline death & $\begin{array}{l}\text { Crude death rate per } 1000 \text { people. } \\
\text { Average between } 1960 \text { and } 1990\end{array}$ & $\begin{array}{c}\text { Constructed using } 1960 \text { (or earlier available value) to } 1990 . \\
\text { World Bank }\end{array}$ \\
\hline wardum & $\begin{array}{c}\text { Dummy for countries that have been involved in a war any } \\
\text { time between } 1960 \text { and } 1990 .\end{array}$ & Sala-i-Martin (2004). From Barro and Lee (1993) \\
\hline $\operatorname{kg} 702007$ & $\begin{array}{c}\text { Share of government consumption to real GDP. } \\
\text { Average between } 1970 \text { and } 2007\end{array}$ & PWT. (Heston et al.) \\
\hline exp_edu & Expenditure in education. & World Bank \\
\hline $\begin{array}{l}\text { fi_sm } \\
\text { innovation }\end{array}$ & $\begin{array}{l}\text { Access to sound money. } \\
\text { Patents per million inhabitants. Closest value to } 1970\end{array}$ & $\begin{array}{c}\text { PRS Group (2012), International Country Risk Guide } \\
\text { World Bank }\end{array}$ \\
\hline $\begin{array}{l}\text { Q3 } \\
\operatorname{logGDP1970}\end{array}$ & $\begin{array}{l}\text { Share of the third quintile in the income distribution. } \\
\qquad \text { GDP (in log). } 1970\end{array}$ & $\begin{array}{l}\text { From WIDER dataset (cross section constructed taking data } \\
\text { for each country in the closest available year to 1970) } \\
\text { PWT. (Heston et al.) }\end{array}$ \\
\hline $\begin{array}{l}\text { pop_growth } \\
\text { mortality } \\
\text { familyf }\end{array}$ & $\begin{array}{c}\text { Population growth rate. } 1970 \\
\text { Infant mortality rate, per } 1000 \text { live births. } 1969 \\
\text { Family farms. As percentage of total cultivated area. }\end{array}$ & $\begin{array}{c}\text { World Bank } \\
\text { World Bank* } \\
\text { Vanhanen's indicators of power resource distribution }\end{array}$ \\
\hline $\begin{array}{l}\text { wheat_sugar } \\
\text { troppop } \\
\text { mount }\end{array}$ & $\begin{array}{c}\text { Proportion of land suitable to wheat compared to land } \\
\text { suitable to sugar (in logs). } \\
\text { Proportion of population living in tropical areas. } \\
\text { Proportion of mountainous land. }\end{array}$ & $\begin{array}{l}\text { Easterly (2007) } \\
\text { Easterly (2007) } \\
\text { Collier (2009) } \\
\end{array}$ \\
\hline \multicolumn{3}{|l|}{ Others } \\
\hline $\begin{array}{l}\text { ki } \\
\text { fertility } \\
\text { schooling2005 } \\
\text { icrg_qog_1984 } \\
\text { riotan } \\
\text { scoup } \\
\text { polrig } \\
\text { assass } \\
\text { attack } \\
\text { democy } \\
\text { execute } \\
\text { repres }\end{array}$ & $\begin{array}{c}\text { Share of investment to real GDP. } \\
\text { Average between } 1970 \text { and } 2007 \\
\text { Fertility rate, } 1970 . \\
\text { Mean years of schooling, age 15+, total. } 2005 \\
\text { Quality of Government Index. } 1984 \\
\text { Number of riots. } \\
\text { Number of successful coups. } \\
\text { Measure of political rights. } \\
\text { Number of assassinations per million population per year. } \\
\text { Number of armed attacks per year. } \\
\text { Index of democracy. } \\
\text { Number of political executions per year. } \\
\text { Number of repressions per year. }\end{array}$ & $\begin{array}{c}\text { PWT. (Heston et al.) } \\
\text { World Bank } \\
\text { World Bank** } \\
\text { PRS Group (2012), International Country Risk Guide } \\
\text { Alesina et al. (1996) dataset } \\
\text { Alesina et al. (1996) dataset } \\
\text { Alesina et al. (1996) dataset } \\
\text { Alesina et al. (1996) dataset } \\
\text { Alesina et al. (1996) dataset } \\
\text { Alesina et al. (1996) dataset } \\
\text { Alesina et al. (1996) dataset } \\
\text { Alesina et al. (1996) dataset }\end{array}$ \\
\hline
\end{tabular}

Notes: * Missing value for Hong Kong filled with those of China. ** Missing values for MDG and NGA filled using International Institute for Applied System Analysis and the Vienna Institute of Demography (IIASA/VID) projections. 
APPENDIX C: List of countries:

\begin{tabular}{ll|ll|ll}
\hline Country & isocode & Country & isocode & Country & isocode \\
\hline Australia & AUS & Honduras & HND & Norway & NOR \\
Bangladesh & BGD & Hong Kong & HKG & Pakistan & PAK \\
Belgium & BEL & Hungary & HUN & Panama & PAN \\
Bolivia & BOL & India & IND & Peru & PER \\
Brazil & BRA & Indonesia & IDN & Philippines & PHL \\
Canada & CAN & Ireland & IRL & Portugal & PRT \\
China & CHN & Italy & ITA & South Africa & ZAF \\
Colombia & COL & Jamaica & JAM & Spain & ESP \\
Costa Rica & CRI & Korea, Republic of & KOR & Sri Lanka & LKA \\
Cote d Ivoire & CIV & Madagascar & MDG & Sweden & SWE \\
Denmark & DNK & Malawi & MWI & Tanzania & TZA \\
Ecuador & ECU & Malaysia & MYS & Thailand & THA \\
Egypt & EGY & Mexico & MEX & Tunisia & TUN \\
El Salvador & SLV & Morocco & MAR & Turkey & TUR \\
Finland & FIN & Nepal & NPL & United Kingdom & GBR \\
France & FRA & Netherlands & NLD & United States & USA \\
Greece & GRC & Nigeria & NGA & Zambia & ZMB \\
\hline
\end{tabular}

